
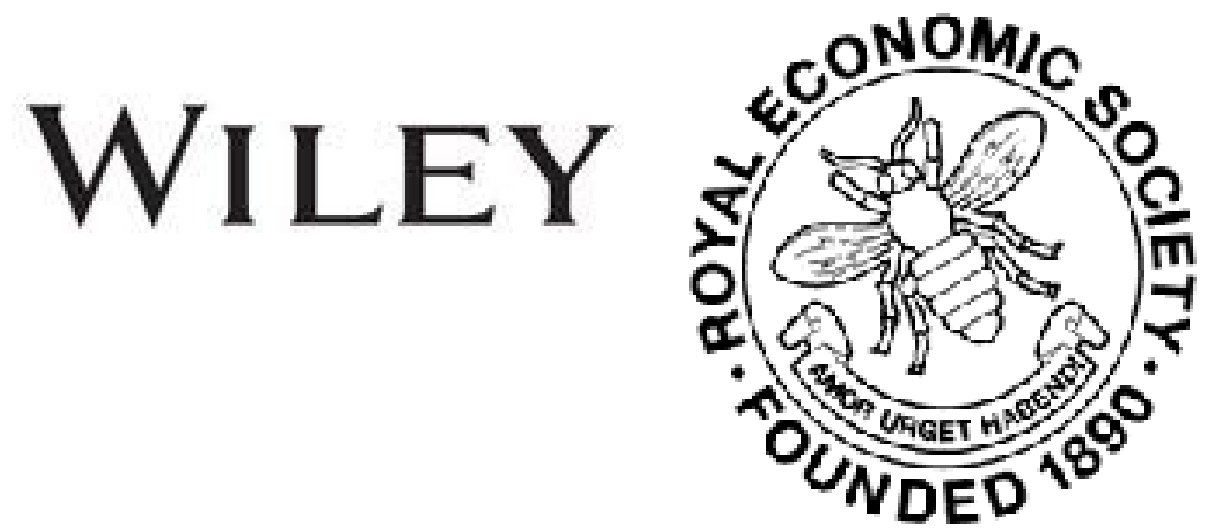

\title{
The Canadian Tariff Revision
}

\section{Author(s): A. W. Flux}

Source: The Economic Journal, Vol. 17, No. 66 (Jun., 1907), pp. 276-283

Published by: Wiley on behalf of the Royal Economic Society

Stable URL: http://www.jstor.org/stable/2220688

Accessed: 26-06-2016 05:05 UTC

Your use of the JSTOR archive indicates your acceptance of the Terms \& Conditions of Use, available at

http://about.jstor.org/terms

JSTOR is a not-for-profit service that helps scholars, researchers, and students discover, use, and build upon a wide range of content in a trusted digital archive. We use information technology and tools to increase productivity and facilitate new forms of scholarship. For more information about JSTOR, please contact support@jstor.org.

Wiley, Royal Economic Society are collaborating with JSTOR to digitize, preserve and extend access to The Economic Journal 
diminution of capital on the land, and in manufactures and commerce; particularly with regard to price, occasioned by the different nature of the instruments employed, one set naturally growing worse, and the other generally growing better. But I have no room for more, so adieu.

Ever truly yours,

T. R. MaLthus

\section{The Canadian Tariff Reviston.}

IN numerous ministerial declarations during the last year or two it was explained that the new tariff was to be framed on the basis of maximum and minimum schedules, with a series of preferential rates lower than those of the minimum schedule. It was supposed that the maximum schedule would be applied to the imports from such countries as Germany and the United States, the minimum schedule to imports from countries which do not subject Canadian exports to their least favourable rates of duty, and which maintain tariff rates at a moderate level.

Such a plan of operation for the Canadian tariff seemed to offer some favourable possibilities. On the one hand, Germany might have ceased to receive a treatment so special as to have the appearance of peculiar ill-will. On the other hand, many interests in Canada would have welcomed the increase of obstacles to importation from the United States, and others would have hoped to secure, as the purchase-price of the concession of the minimum rates to the United States, a substantial scaling-down of the existing extravagant rates of duty with which Canadian exporters are met in that direction.

Mr. Fielding's speech revealed an arrangement even more complicated than had been foreshadowed. The special surtax applying to Germany has been retained unaltered, the rates being one-third above those of the ordinary tariff. As this ordinary tariff is thus not one of maximum rates, it retains the old title of general tariff. The principle of the maximum and minimum plan is, however, embodied in the new scheme, in the shape of an intermediate table of rates, about one-tenth below those of the general tariff, on the average, though numerous rates are identical in the two schedules, and in a considerable number of cases the intermediate rates are exactly half-way between the general and preferential rates. The intermediate tariff is to be applied to imports from countries which 
give adequate concessions in their own tariffs to imports from Canada. If Mr. Fielding's meaning was correctly interpreted, the intermediate rates represent the extreme of the concessions which non-British countries will be able to secure from Canada. The entire list of intermediate rates may or may not be conceded to any one country in return for what it gives, so that, if a country be unwilling to give adequate concessions, it will secure a correspondingly meagre share of the advantages presented by the intermediate tariff. If this be the correct interpretation of Mr. Fielding's words and manner when presenting the subject, some not inconsiderable difficulties may arise. Of these the chief is that presented by "most favoured nation" clauses in British treaties which apply to Canada, unless those clauses are to be given the American interpretation, and held to promise merely reciprocal concession of terms as favourable as those granted to any other nation. The Finance Minister referred to the obstacle presented by these treaties. He suggested that it might be possible to conclude arrangements with several countries, to take effect at about the same time. If we examine the trade returns for 1905-6, we find that 95 per cent. of the dutiable imports from non-British countries were received from the following six, viz.: United States (which contributed 75 per cent.), France, Germany, Belgium, Switzerland, Japan. Now, of these, no difficulty would arise in the case of the United States, Germany, or Belgium, since the grant of special terms to other countries would not involve the extension of those favours to either. Canada has learned from experience that both France and Japan are willing to meet her in trade matters. By including only five other countries, or, in strictness, four only, over 98 per cent. of the dutiable imports are covered, and two million dollars only left for all other countries. These four are Holland (including the Dutch East Indies), Spain, AustriaHungary, and Italy. Most-favoured-nation treaties only affect Canada's relations to Austria-Hungary and Spain of these. Even of the small remainder of two million dollars, one-third is derived from Cuba and Porto Rico, and the American interpretation of the most-favoured-nation clause may perhaps apply to these. It will thus be seen that the obstacles in the way of action looking towards the application of the intermediate tariff are not as great as has been represented in some quarters. Could satisfactory reciprocity treaties be arranged with France and Switzerland, Austria-Hungary, Spain, and Japan, they might be put into force without waiting for treaties with the rest of the world, No. 66.- -voL. XVII. 
especially as a number of the minor countries are, like some of those named above, not entitled to claim from Canada the mostfavoured-nation treatment.

The relation of the United States and Germany to the new intermediate tariff has attracted a large amount of attention. It has been freely stated that both would, as a matter of course, proceed to qualify for the favours embodied in it. As to this, it may be said at least that there are grave reasons for doubting the accuracy of such a prophecy. The retaliatory spirit expressed in the surtax imposed in Canada on German goods, and in the action which provoked it, by which Canadian goods are subject to the rates of the German maximum tariff, is rather different from the friendly exchange of reciprocal favours which the offer of the intermediate tariff is meant to evoke. It is true that hopes are expressed at Ottawa that a better relationship with Germany may be arranged in the near future, and it might happen that the German minimum tariff would be considered sufficiently favourable to Canada to warrant, not merely the abandonment of the surtax, but the grant of the intermediate rates. If that were to happen, German competition with some lines of British trade in Canada, severe in spite of the burden of the surtax, might become very serious.

As to the prospect of reciprocity between Canada and the United States, the immediate future, seems to promise little definite movement. The utterance of Sir Wilfrid Laurier in the House of Commons on January 14th expresses the opinion of most well-informed people. The Canadian Premier said :-

"I do not think it would be possible to obtain from the United States, at the present time, or at any time, any quid pro quo in the way of trade concessions. We have been looking for trade concessions for a long time, but we do not look for them any more now; we have abandoned that idea long ago. We do not care any more to have these trade concessions. There was a time when we would have given a great deal to have trade concessions from our American neighbours; they chose in their own way to refuse these; we have done pretty well without them, and at the present time we do not expect anything of that nature."

The official statements of the Canadian Manufacturers' Association, professing fear that the application of the intermediate tariff to the United States would soon be realised, and would threaten the existence of numerous Canadian factories, need not be taken too seriously. They are opposed to all that can be 
learned as to the disposition of the Congress of the United States, and especially of the Senate.

Whether the intermediate tariff remain as an exhibition of what Canada is willing to do, an offer which none accept, or not, it may be said to express anew the spirit of the reciprocity offer of the tariff of ten years ago. That offer of reciprocity was quickly changed so as to apply only within the limits of the British Empire. It had served an end in procuring the denunciation of the Belgian and German treaties. It seemed, almost, that the new scheme of the Canadian Government might be designed to procure the denunciation of all the British mostfavoured-nation treaties which include Canada within their scope. What has been stated above makes it appear that such action is not necessary to enable Canada to act effectively in the promotion of her own trade interests as may seem best to herself.

Passing, now, from the most novel feature of the new tariff to the changes in the preferential rates, we find realised the anticipated replacement of a uniform rebate of one-third by preferential rates varying from item to item. The principal line of change has resulted from the application of a rule that every rate of duty shall be a multiple of $2 \frac{1}{2}$ per cent. On rates like 20,25 , or 35 in the general tariff, the one-third rebate produced some awkward fractions in the preferential rates. In the new tariff all these are abolished, a result achieved, sometimes by raising, sometimes by lowering the rate of the preferential duty. Thus, in the old tariff, cotton fabrics, white or gray, bleached or unbleached, were charged at 25 per cent. The preferential rate was thus 162 per cent. In the new tariff the general rate is unchanged, but the preferential rates are made different, that on white fabrics being raised to $17 \frac{1}{2}$ per cent., while that on gray goods is lowered to 15 per cent. A few items, about a dozen in all, have the same rate of duty whatever their origin, being treated in the same way as tobacco and alcoholic liquors in the old tariff. The new items are all charged at low rates, 5 or 10 per cent. They include stereotypes, on which the duty is halved, while stereotypes in foreign languages, formerly free, are no longer treated differently from those in English or French.

There is also a list of a dozen items, half of which were formerly in the free list, which are free under the preferential tariff, and bear small duties under the other tariffs. This has involved imposing duties on some items when imported from other than British sources. Salt, celluloid in the rough, curling 
stones, and some kinds of iron and steel wire are now dutiable when non-British in origin, while the duty on dry red lead, and some varieties of iron and steel sheet and pipe, remains when they are of foreign origin, but is abolished when they come under the preferential tariff. There are a few transfers between the free list and the dutiable list, of which examples are : uncleaned rice now free, the duty on cleaned rice being correspondingly reduced; and paintings, formerly free if "by artists of wellknown merit," now dutiable at 25 per cent. under the general tariff, 15 per cent. under the preference, with a limit of fifty dollars chargeable on any one painting or pastel.

Besides such changes in the free list, some of which may prove of considerable importance, a new plan of dealing with certain materials of manufacture is adopted. Both the old and the new tariff provide numerous instances of specially low duties or freedom from duty for materials, otherwise subject to the ordinary scale of duty, when these materials are imported by manufacturers for working up in their own establishments. The new tariff tries a novel plan of controlling such importation. The specified materials are to be regularly imported, and, when they are worked up into goods sold for home consumption, the manufacturer is to be able to claim a drawback, which is, in the great majority of cases, 95 per cent. of the duties paid. In nearly all these cases the materials had previously been on the free list. In one case, where the drawback is 50 per cent., the previous arrangement had been to admit the material for the use of the manufacturer at 15 per cent. duty (preferential rate 10 per cent.). The new plan reduces the burden somewhat, but, as the duties of which the half are to be refunded are much higher than the old 15 per cent., the change in the situation is much less than appears at first sight. Some complaint has been heard that manufacturers of iron and steel are to be deprived of an important part of the home market by the new drawback arrangement, but a comparison of the actual conditions under the old and new tariffs shows that no more than a little extension of the range of materials admitted on special terms for manufacturing purposes has been effected. On the other hand, in these special cases, the manufacture for export will receive no encouragement under the new scheme. The same principle applies to the bounties on steel, of which more presently, which are not to be paid on this commodity when produced for export. Canada is not to be made a basis from 
which the United States Steel Corporation, by establishing Canadian branches, may secure favourable entry for its goods into markets which are more freely open to Canadian goods than to like goods from the United States.

Turning to the question of the level of the rates of the new tariff, space will not admit of any lengthened analysis in this letter. Some guidance in judging of the effects of the changes may be gained from a few tentative comparisons. The three most important groups of articles, so far as British trade is concerned, are woollens, cottons, and iron and steel. Consider first the woollen schedule. Here, as will be remembered, a change was made in 1904, by which the preferential duty on certain classes of woollen goods was made 30 per cent., less than the general duty by only 5 per cent., or one-seventh in place of the usual one-third. The new tariff maintains this arrangement, and even extends it to embrace some goods formerly tariffed separately and lower, by the simple process of omitting the specific mention of these additional goods. Seventy per cent. in value of the "wool and woollens" imported in the last complete fiscal year fell under this classification. The net result is to increase slightly both general and preferential duties, though the former in so small a degree as to be, negligible. The increases in preferential rates are somewhat greater than the decreases, though, on the entire mass of woollens, the net increase is only about one-tenth of 1 per cent. of the value of the goods.

Turning to cottons, we find that the goods affected by decreased preferential rates represented less than 8 per cent. of the imports of cottons from Great Britain in 1905-6. The goods with unchanged preferential rates were between 11 and 12 per cent. of the total. Thus the preferential rates are raised, whether by little or by much, on over 80 per cent. of the goods, judging by the standard of last year. The aggregate net increase is about 1 per cent. of the value of the goods, which shows that the changes are mainly those due to introducing the $2 \frac{1}{2}$ per cent. step system. It is to be observed, however, that the rates of the general tariff are reduced, and by an average amount of about $1 \frac{1}{4}$ per cent. Thus the difference, constituting the preference, which was formerly about 10 per cent. of the value of the goods, is reduced by more than one-fifth of its amount.

In iron and steel goods the changes made are more favourable to British trade. Reference has already been made to cases where, with small duties retained or imposed in the general tariff, 
the preferential tariff shows no duty. When we sum up the results, the few cases of increased preferential rates are considerably outweighed by the more numerous cases of decrease. At the same time the general tariff rates average a little more than under the tariff of 1896 . The result is that a preferential difference of a little over 6 per cent. of the value of the goods is replaced by one of over 8 per cent., or an increase in the advantage open to British traders in the proportion of 3 to 4 . The actual advantage may be greater than this, since the differences in excess of the average are those which, if any, are likely to become operative in affording openings for transfer of business from the United States to Great Britain. ${ }^{1}$

The rearrangement of the tariff rates is not intended to expose Canadian manufacturers of iron and steel to severer competition, but to offer an opportunity for diverting to the home country some of the trade which now goes elsewhere. The home manufacturer receives special consideration in a revision of the bounties, which were on the point of expiring. In place of disappearing at the end of June next, they are to be continued till the end of 1910, and for this year and next to be set at a level substantially higher than that which was reached last year. Further, the use of Canadian ore is favoured by making the difference between the bounties, on iron from Canadian and imported ore, one dollar per ton of $2,000 \mathrm{lb}$., or about $4 s$. $7 \frac{1}{2} d$. per English ton.

Three other points must be noted in the revised tariff. One relates to the conditions under which goods qualify for preferential tariff rates. The proportion of their value due to British labour must be 25 per cent. at least, and this 25 per cent. is to be henceforth clear of either manufacturers' or merchants' profit. The second relates to the special provisions against dumping. This special duty was, except in a few cases, limited to one-half the regular customs duty on the article. The limit is now made in all cases, as in the special cases referred to, 15 per cent. of the value. The third point relates to the provision for meeting combinations of manufacturers to unduly exalt prices. The regular procedure in such a case has been that a special inquiry was held to determine whether the combination really existed and worked the injurious result deprecated. An alternative method of establishing the facts is now found wher-

1 Further changes in the rates, made during the discussion of the Tariff in the House of Commons, have tended to increase the preference on iron and steel goods somewhat beyond the amount indicated in the figures given. 
ever the case has been adjudicated upon by the ordinary courts of law. In such a case no delay for a new and special inquiry will be necessary in the future.

Some special attention has been given to one other important change in the tariff rates, affecting the differential between the rates on raw and on refined sugar. The opinion was expressed by the Finance Minister that the sugar refiners have been securing a larger advantage than had been intended. Since the introduction of the surtax on German goods the imported raw sugars have become almost exclusively West Indian (including Guiana under this designation for convenience). The new tariff leaves the duties on refined sugar unchanged, but increases the duty on raw sugar by $7 \frac{1}{3}$ cents per hundred pounds if from British sources, and by 12 cents if foreign. For sugar at 96 degrees the new rates are 55 and $83 \frac{1}{2}$ cents per hundred pounds for British and foreign sugars respectively. The rates on refined at the same polariscope standard are, as before, 80 cents and $\$ 1.20$ respectively. The new rates should give British raw sugar a greater advantage than ever, and either make it easier to import British refined or prevent the Canadian refiners from transferring the addition to the duty to the consumers of sugar.

This letter has already reached an inordinate length, so that other topics must be postponed.

Montreal, Feb. 7th, 1907.

A. W. Flux

P.S.-Of the changes in the original draft of the new tariff, which were effected during the passage of the Tariff Bill through the House, it is hardly necessary to write at length, especially in view of the fact that British interest in matters Canadian has been recently diverted to what was passing at the Colonial Conference. It may, however, be worth while noting one fact. An attempt was made to amend the Government proposals by confining preferential treatment to imports made directly to Canadian ports, refusing it to imports via United States ports. Though this condition for preferential treatment is not to be imposed at present, power has been given to the Governor in Council to impose it when the conditions appear favourable. Ministerial declarations were to the effect that until the new transcontinental railway is built, such a measure would be inadvisable. The attempt and its results are indicative of strong currents of opinion in the Dominion.

May 1st, 1907.

A. W. F. 